\title{
Article
}

\section{Can We Share? Feeding Strategy in Three Syntopic Newts in Artificial Habitats}

\author{
Luca Stellati $^{1}$, Jennifer Mirabasso ${ }^{1}\left(\mathbb{D}\right.$, Luca Luiselli $^{2,3,4}{ }^{\circledR}$, Marco A. Bologna ${ }^{1}\left(\mathbb{D}\right.$, Leonardo Vignoli ${ }^{1} \mathbb{C}$ \\ and Alessandra Maria Bissattini ${ }^{1, *(\mathbb{C})}$
}

1 Dipartimento di Scienze, Università Roma Tre, Viale Marconi, 446, 00146 Rome, Italy; luca.stellati@uniroma3.it (L.S.); jennifer.mirabasso@hotmail.it (J.M.); marcoalberto.bologna@uniroma3.it (M.A.B.); leonardo.vignoli@uniroma3.it (L.V.)

2 IDECC, Institute for Development, Ecology, Conservation and Cooperation, Via G. Tomasi di Lampedusa 33, 00144 Rome, Italy; 1.luiselli@ideccngo.org

3 Department of Animal and Environmental Biology, Rivers State University of Science and Technology, P.M.B. 5080 Port Harcourt, Nigeria

4 Department of Zoology, University of Lomé, 01 BP 1515 Lomé, Togo

* Correspondence: alessandramaria.bissattini@uniroma3.it

\section{check for}

updates

Citation: Stellati, L.; Mirabasso, J.; Luiselli, L.; Bologna, M.A.; Vignoli, L.; Bissattini, A.M. Can We Share? Feeding Strategy in Three Syntopic Newts in Artificial Habitats. Diversity 2021, 13, 32. https://doi.org/ $10.3390 / \mathrm{d} 13010032$

Received: 26 November 2020

Accepted: 11 January 2021

Published: 15 January 2021

Publisher's Note: MDPI stays neutral with regard to jurisdictional claims in published maps and institutional affiliations.

Copyright: (c) 2021 by the authors. Licensee MDPI, Basel, Switzerland. This article is an open access article distributed under the terms and conditions of the Creative Commons Attribution (CC BY) license (https:// creativecommons.org/licenses/by/ $4.0 /)$.

\begin{abstract}
Natural aquatic sites are disappearing worldwide, especially in the Mediterranean region where amphibians are frequently forced to move for reproduction to artificial sites designed for irrigation and cattle watering (i.e., wells, tanks and drinking troughs). In artificial aquatic sites, where resources (space and food) are usually limited, trophic niche information can be particularly useful to infer the suitability of habitats for amphibian conservation especially when more than one species co-occurs. In this paper, we focused on three newt species: The Italian newt (Lissotriton italicus), the Italian smooth newt (Lissotriton vulgaris meridionalis) and the Italian crested newt (Triturus carnifex) inhabiting man-made wells widespread in an area in Central Italy characterized by few available natural aquatic sites. Specifically, we analyzed the trophic spectrum of the species, their interactions and overlap, and discussed the potential role of wells in amphibian conservation. Overall, 550 newt individuals occurring in 16 distinct wells were sampled. The study species consumed similar resources, mainly of aquatic origin, with Diptera larvae and Cladocera representing the most important preys. The high degree of diet overlap observed may be due to site oligotrophy and high availability of small-sized prey, and it does not necessarily lead to competition. Newts had similar narrow niche width values and a generalist feeding pattern with high diversity among individuals. Lissotriton italicus and T. carnifex showed wider niche width in isolation than in syntopy condition, probably as a result of interspecific competition and/or intraguild predation. We showed that artificial aquatic sites are important for newt ecology and conservation since they allow up to three species to cohabit, thus representing a good surrogate of natural habitats. The study wells apparently provided suitable trophic conditions for newts in terms of prey availability and catchability. To date, just a few studies have contributed to a greater understanding of newts' diet in artificial aquatic sites and this gap of knowledge has to be filled to clarify their role in amphibian ecology and conservation.
\end{abstract}

Keywords: amphibians; feeding ecology; niche width; artificial habitats; niche overlap; trophic interactions

\section{Introduction}

Widespread amphibian declines have become a critical issue in Conservation Biology during the past two decades, especially in the Mediterranean region where reproductive sites are increasingly disappearing because of habitat loss, alteration and fragmentation caused by agricultural intensification and urban development [1]. However, artificial sites specifically designed for irrigation and cattle watering (i.e., wells, tanks and drinking troughs) may represent an important contribution to the potential breeding habitats for 
amphibians [2]. However, the role of artificial habitats for the resilience of amphibian populations has not been deeply investigated and the ecology and conservation of amphibians in such habitats is almost neglected [3].

In the Mediterranean region, newts have adapted to breed in temporary ponds and streams [4], especially in Italy where assemblages of up to three sympatric species may occur [5-8]. In temporary ponds and streams, newt community structure may be shaped by complex interactions including intraguild predation, environmental stochasticity and competition for habitat use and food resources [9]. Sympatric newts feed mostly on arthropods and differ in their interspecific feeding strategy and degree of specialization [10]. Their diet may be influenced by both individual (e.g., age, size, and sex) and environmental features (e.g., landscape, prey types and others biotic and abiotic factors) $[5,11]$.

In the present study, we focused on three newt species that are known to successfully colonize artificial aquatic sites during the breeding season [12]: The Italian newt (Lissotriton italicus), the Italian smooth newt (Lissotriton vulgaris meridionalis) and the Italian crested newt (Triturus carnifex). The first two species are respectively endemic and subendemic of the Italian peninsula $[13,14]$, whereas the latter shows a disjunct distribution between the Italian and Balkan peninsulas [15].

In the present study we analyzed the trophic spectrum of the above-mentioned study species in distinct assemblages (up to three co-occurring species) in artificial aquatic habitats. Several studies have contributed to a greater understanding of newts' diet in artificial sites, but they were mostly focused on natural-like waterbodies (i.e., ponds; [7,16-18]), whereas trophic interactions in non-natural shape waterbodies (i.e., drinking throughs) remained less investigated [19]. Specifically, we aimed at:

1. Describing and comparing the diets of newt species, with a special emphasis on the effect of the occurrence heterospecific individuals. This issue is noteworthy since the occurrence of heterospecific individuals (i.e., isolation vs. co-occurrence condition) is expected to influence species' trophic strategy in terms of resource partitioning [7]. Indeed, heterospecific individuals may narrow or widen species' niche reducing the available resources uniformly (expansion) or in a patchy manner (contraction) [20,21]. A reduction in food diversity may further decrease species' trophic niche width $[22,23]$.

2. Investigating species interactions in terms of trophic niche overlap, since syntopic salamanders are known to assemble in a non-random fashion with food niche and morphological features playing a key role in structuring community composition [24]. Specifically, newt species with similar niche width and different body sizes are expected to show a low overlap in resource use.

To address all these issues, we selected an area in Central Italy where the study species inhabited exclusively artificial wells used as water reservoirs for cattle watering and traditional agricultural practices. Wells are permanent water bodies (i.e., hydroperiod lasts well beyond the duration of newt aquatic phase) with simplified structure and closed physical boundaries, thus representing a sort of seminatural mesocosms present in several replicates across a small geographic range [25]. All these features make wells a good system to study the ecology of newt populations, their assemblage composition and possible interspecific interactions $[3,8]$.

Understanding the association of newts with artificial aquatic sites may represent a useful tool for effective conservation strategies of amphibians, especially in areas where original habitats have been degraded and/or lost [2,3]. Such kind of studies are timely since most of the artificial habitats associated with traditional agriculture and cattle watering are disappearing because of the adoption of modern and intensive farming practices and the abandonment of traditional irrigation methods [3,26]. 


\section{Materials and Methods}

2.1. Study Area

Using satellite images (Google Earth ()) and site visits, we identified wells within an area covering approximately $200 \mathrm{~km}^{2}$ in the Aurunci Mountains within an altitude range of $360-830 \mathrm{~m}$ a.s.l. (Lat. $41^{\circ} 27^{\prime} \mathrm{N}-41^{\circ} 18^{\prime}$, Long. $12^{\circ} 23^{\prime} \mathrm{E}-13^{\circ} 45^{\prime} \mathrm{E}$, anti-Apennines of Latium Region, central Italy; Figure 1). Field work was carried out within the "Monti Aurunci Regional Park" which is characterized by Mediterranean scrubs (Spartium junceum L., Myrtus communis L., Pistacia lentiscus L., Arbutus unedo L., Calluna vulgaris L., Erica spp.) and woodlands (Quercus ilex L.) in the southern part and forests characterized by several arboreal species (Ostrya carpinifolia Scopoli, Carpinus orientalis Miller, Fraxinus ornus Linnaeus) in the northern side whereas at higher altitudes forests are dominated by Fagus sylvatica Linnaeus and intermitted with grasslands [27].

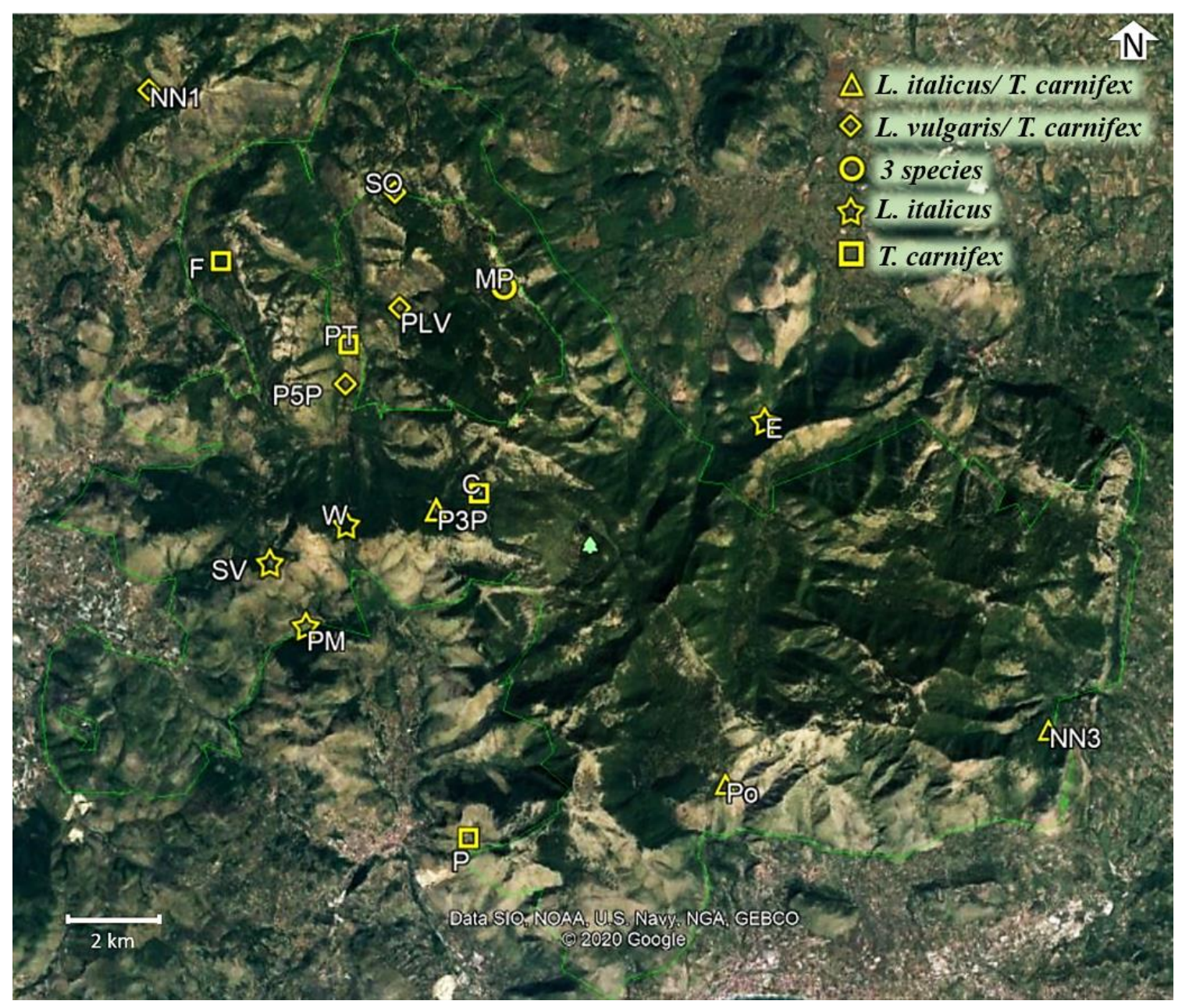

Figure 1. Distribution map of wells in the study area with indication of species coexistence. The numbers on the map refer to the well ID (Google Earth, earth.google.com//).

The "Monti Aurunci Regional Park" is an ideal candidate for this kind of study since wells associated with traditional husbandry and agriculture are quite common because of the scarcity of natural aquatic systems [28] frequently used as breeding sites by all the study species [12]. Wells represent permanent water reservoirs characterized by circular shape, vertical walls, high depth (up to $6 \mathrm{~m}$ ) and an extremely scanty aquatic vegetation, mainly dominated by Potamogeton spp. and Chara spp., and small patches of riparian vegetation and algae (Figure 2). All study sites were fishless and surrounded by pastures with the 
exception of two wells, immersed in forest dense vegetation. Odonata and coleoptera larvae were the only potential predators that commonly co-occurred with. the study species.



Figure 2. An example of the wells used as water reservoir in the study area. The structure makes them easy to be colonized by newts due their vertical stony walls and the upper margin on the ground level.

\subsection{Samplings and Data Collection}

Adult newts were collected at daytime during the breeding season of all three species (March-July) [12]. Wells were sampled once each by the same two-person team between March 18th and June 21st, 2019. Individuals were visually located and captured when surfacing to breathe by means of a long-handled dip net ( $3.5 \mathrm{~m}$ in length) from the shore. Immediately after capture, newts were marked by a photograph of the ventral pattern, measured (SVL $=$ snout-vent length to the nearest $0.001 \mathrm{~mm}$ ) and sexed based on secondary sexual characters [12]. Individuals were stomach flushed using a $10 \mathrm{ml}$ syringe equipped with a plastic tube with an external diameter of $2 \mathrm{~mm}$ [29] and temporarily housed in tanks filled with water for approximately two hours to verify their return to normal activity. No mortality has been observed during or after stomach flushing.

Food items were individually stored in vials containing $70 \%$ ethanol solution, identified under a stereomicroscope (Olympus SZX 12. Range of magnification 9-55X) and classified according to order. Prey were photographed by a digital camera (Panasonic Lumix, FZ20) and the maximum length and width of each item (excluding antennae and cerci) were measured by means of ImageJ software (https:/ /imagej.nih.gov/ij/; Version 1.52h; Bethesda, MD, USA).

Food composition was analyzed in terms of number, occurrence, and volume of each prey category. The volume of each item $\left(\mathrm{mm}^{3}\right)$ was calculated using the formula for an appropriate three-dimensional solid: cylinder $\mathrm{V}=\mathrm{L}^{*}(\mathrm{~W} / 2)^{2} \pi$ (i.e., worms, insect larvae and pupae) or spheroid $\mathrm{V}=4 / 3 \pi^{*}(\mathrm{~L} / 2)^{*}(\mathrm{~W} / 2)^{2}$ (i.e., adult insects, crustaceans, spiders) $[7,30]$, where $L$ corresponds to the greatest length and $W$ to the largest width of the prey. Larvae and adult insects were considered separate food items because their habitat, mobility, and caloric contents are usually different [31]. In case of fragmented 
or partly digested food items, the volume was estimated using measurements made on intact items [30]. When an item was highly fragmented/incomplete, we used taxonomic identification keys and/or we referred to similar intact items found in other stomachs. In addition, each prey type was classified as aquatic or terrestrial, depending on the stage of development and the habitat in which it occurred [7]. The ingestion of plants and minerals was considered accidental and not included in further analyses.

\subsection{Body Size and Diet Composition}

Analysis of variance (ANOVA) was performed to compare snout-vent length (SVL) among newt species, across study sites and between sexes. Spearman's rank correlation was carried out to test whether SVL was related to the mean volume and number of food items ingested.

An index of importance (IRI) was calculated for each prey category by the formula proposed by Pinkas et al. [32]:

$$
\mathrm{IRI}=\left(\mathrm{P}_{\mathrm{Ot}}\right)^{*}\left(\mathrm{P}_{\mathrm{It}}+\mathrm{P}_{\mathrm{Vt}}\right)
$$

where $\mathrm{P}_{\mathrm{Ot}}$ is the percentage of occurrence, $\mathrm{P}_{\mathrm{It}}$ is the percentage of prey number and $\mathrm{P}_{\mathrm{Vt}}$ is the percentage of prey volume.

Hurlbert's standardized index of niche width, estimated on both numeric and volumetric data, was calculated for each species and sex as:

$$
\mathrm{B}^{\prime}=(\mathrm{B}-1) /(\mathrm{n}-1),
$$

where $B^{\prime}$ is the standardized index of niche width, B is Levin's Index [33] and $n$ is the number of prey types [34]. Niche width was considered as low (0-0.39), intermediate $(0.4-0.6)$ or high $(0.61-1)$ [35].

\subsection{Comparison in Diet Composition among Species and between Sexes}

Differences in prey volume and number among species were analyzed using ANOVAs. ANOVAs were also used to test whether numeric and volumetric niche width values differed among species, between sexes and condition of syntopy. Lissotriton vulgaris was excluded from this kind of analysis since it has always been found in syntopy with other newt species at the study area [20].

Graphic visualization of Costello [36], modified by Amundsen et al. [37], was used to analyze the feeding strategy (generalist/specialist) of the species and the importance of specific food items in their diet. Such a method classifies prey selection by plotting prey-specific abundance [ $\mathrm{Pi}$ is the proportion of a prey item $(\mathrm{j})$ in those individuals in which prey $\mathrm{j}$ occurs] on the $y$-axis against frequency of occurrence on the $x$-axis [37].

The niche overlap among species and between sexes was measured by means of Pianka's index [38]. $3 \times 10^{4}$ Monte Carlo permutations of the original matrices were generated by means of Lawlor's randomization algorithm RA2 to compare the observed index to a simulated value obtained from a proper null model [38]. RA2, considered more effective in discovering assemblage structure in generalist ectotherm vertebrates than other algorithms, maintains the zeroes in the matrix and replaces every other cell with a randomly chosen uniform number between 0 and 1 [24,39].

A nested PERMANOVA design with species and sex as fixed factors and study sites as random factors nested in species was carried out to determine whether there were any differences in diet composition considering the number of food items as dependent variable [40]; Vegan package 2.5-6; [41]). This analysis was performed on a Bray-Curtis similarity matrix and 999 permutations, computed with data transformed to presence/absence. Since PERMANOVA uses similarity measures, the rejection of the null hypothesis indicates that groups may differ due to their location (in the multivariate space), their relative dispersion, or both [40]. This suggests that, although PERMANOVA is known to be more robust than other multivariate tests [42], it may be affected by variations in dispersion [43]. 
Therefore, a multivariate form of Levene's test for homogeneity of variances was used to assess dispersion of samples (Vegan package 2.5-6; [41]). If PERMANOVA revealed differences for the interaction term "species*site", a SIMPER analysis was carried out to identify the prey orders that most contributed to the dissimilarities found [44].

Furthermore, a nested Analysis of Similarity (ANOSIM; [44]) was performed with the same model and Bray-Curtis matrix to measure dissimilarities in diet composition among species and between sexes [44]. ANOSIM produces an R statistic highlighting the extent to which the groups differ; $R$ values range from 0 to +1 . The greater the distance from zero, the more different groups are from one another. Differences were considered as weak $(R \leq 0.25)$, moderate $(0.26 \leq R \leq 0.50)$ or strong $(R \geq 0.51)$ [45]. $P$ values generated by ANOSIM were not considered for inference as these values are permutation-based and affected by sample size [46]. Only newts with at least three prey items in their stomachs were considered to avoid overestimation.

We used parametric and non-parametric tests based on whether the assumption of normality was met. ANOVAs were performed using STATISTICA (version 8.0 for Windows). Null model analyses on niche overlap were conducted in EcoSim software (version 7.0; [38]). ANOSIM procedure and PERMANOVA were carried out in R Core Team (Vegan package 2.5-6; [41]). SIMPER procedure was conducted in PAST (version 3.0 for Windows; [47]. All the tests were two-tailed and the alpha level set at 0.05.

\section{Results}

\subsection{Body Size and Diet Composition}

Overall, 16 wells and 25 newt populations were surveyed (eight for L. italicus, five for L. vulgaris and 12 for T. carnifex). Lissotriton italicus (LI) and T. carnifex (TC) occurred in isolation in four study sites each whereas L. vulgaris (LV) was found always in syntopy with TC (four sites). LI-TC assemblage occurred in three sites, whereas all the study species were found together at only one site. A total of 550 newts were sampled and stomach flushed (150 LI, $167 \mathrm{LV}$ and $233 \mathrm{TC}$ ). Body size (mean \pm SD; $3.458 \pm 0.383 \mathrm{~cm}$ for LI, $4.281 \pm 0.273 \mathrm{~cm}$ for $\mathrm{LV}$, and $7.028 \pm 0.716 \mathrm{~cm}$ for TC) significantly differed among species with TC $>>$ LV > LI (Kruskal-Wallis ANOVA; $\mathrm{H}_{2,549}=465.623, p<0.001 ; p<0.001$ for all post hoc comparisons). Within each species, SVL varied between sexes with females always larger than males $(p<0.001)$ and across study sites ( $p<0.001$ for all species). Food items were detected in the digestive tracts of $95 \% \mathrm{LI}, 98 \% \mathrm{LV}$ and $97 \% \mathrm{TC}$. The diet of the study species was mainly composed of Cladocera and Diptera larvae, the former dominating the food composition of $\mathrm{LV}(\mathrm{IRI}=6930.532, \mathrm{FO}=71 \%)$ and the latter representing the most important prey in $\mathrm{LI}(\mathrm{IRI}=2175.647, \mathrm{FO}=59 \%)$ and $\mathrm{TC}(\mathrm{IRI}=1867.151, \mathrm{FO}=60 \%)$. Aquatic prey dominated numerically and volumetrically the diet of all the study species (Table 1).

Aquatic prey dominated the diet of both sexes in all the study species (Table S1). No correlation between mean prey volume and the body size of newt species was found $(p=0.130)$. All the study species showed narrow niche width for both numeric and volumetric data (Table 2). Numeric and volumetric niche width were low and did not differ between sexes, a pattern consistent among species ( $p$ always $>0.05$ ) (Table 2; Table S1).

\subsection{Feeding Strategy and Comparison of Diet Composition among Species and between Sexes}

Significant differences in prey volume of newt species were found with TC and LI consuming larger prey than LV $(\mathrm{F} 2,526=18.617, p<0.001)$. TC and LV consumed a higher number of prey than $\mathrm{LI}\left(\mathrm{H}_{2,532}=27.894, p<0.001\right)$. Within all the species, sexes did not differ in the number and volume of the prey consumed ( $p$ always $>0.05$ ). 
Table 1. Diet composition of Lissotriton italicus, Lissotriton vulgaris and Triturus carnifex. The number of stomachs examined is reported in brackets. $\mathrm{N} \%=$ percentage of prey number; $\mathrm{V} \%=$ percentage of prey volume; IRI = index of relative importance; $\mathrm{B}^{\prime}=$ Hurlbert Index values; ad = adult; 1 = larvae; ne = neanids; ny = nymphs; pu = pupae. Asterisks $\left(^{*}\right)$ show values $<0.001$.

\begin{tabular}{|c|c|c|c|c|c|c|c|c|c|}
\hline \multirow[b]{2}{*}{ PREY } & \multicolumn{3}{|c|}{ L. italicus (142) } & \multicolumn{3}{|c|}{ L. vulgaris (163) } & \multicolumn{3}{|c|}{ T. carnifex (227) } \\
\hline & $\mathrm{N} \%$ & $\mathrm{~V} \%$ & IRI & $\mathrm{N} \%$ & $\mathrm{~V} \%$ & IRI & $\mathrm{N} \%$ & $\mathrm{~V} \%$ & IRI \\
\hline \multicolumn{10}{|l|}{ Aquatic } \\
\hline Acanthocephala & 0 & 0 & 0 & 0 & 0 & 0 & 0.019 & $*$ & 0.009 \\
\hline Amphipoda & 7.553 & 0.143 & 216.807 & 2.081 & 0.201 & 47.6 & 2.361 & 0.053 & 35.105 \\
\hline Bivalvia & 1.033 & 1.911 & 4.146 & 0.059 & 0.543 & 0.739 & 1.312 & 2.859 & 16.537 \\
\hline Cladocera & 24.919 & 1.467 & 836.189 & 76.036 & 22.197 & 6930.532 & 51.406 & 3.607 & 1841.815 \\
\hline Coleoptera ad & 0.194 & 0.324 & 1.094 & 0.04 & 0.205 & 0.3 & 0.094 & 0.214 & 0.678 \\
\hline Coleoptera 1 & 1.097 & 1.037 & 18.035 & 0.02 & 0.061 & 0.05 & 0.319 & 0.237 & 1.958 \\
\hline Crustacea & 0.194 & 0.165 & 0.757 & 0 & 0 & 0 & 0.056 & 0.001 & 0.051 \\
\hline Diptera 1 & 28.018 & 8.761 & 2175.647 & 7.77 & 18.643 & 1490.801 & 16.229 & 14.936 & 1867.151 \\
\hline Diptera pu & 6.068 & 12.947 & 629.371 & 1.467 & 15.436 & 342.212 & 6.428 & 16.108 & 804.144 \\
\hline Ephemeroptera 1 & 1.743 & 1.801 & 37.436 & 0.178 & 0.909 & 6.005 & 0.731 & 0.897 & 19.357 \\
\hline Gastropoda & 0.065 & 0.326 & 0.275 & 0.178 & 4.447 & 19.865 & 2.211 & 13.338 & 253.448 \\
\hline Isopoda & 5.1 & 50.518 & 705.017 & 0.238 & 11.622 & 65.485 & 1.087 & 12.214 & 70.315 \\
\hline Nematoda & 0.065 & * & 0.046 & 0 & 0 & 0 & 0 & 0 & 0 \\
\hline Odonata & 0 & 0 & 0 & 0 & 0 & 0 & 0.056 & 1.04 & 1.448 \\
\hline Odonata 1 & 0.646 & 1.456 & 11.838 & 0.059 & 7.252 & 13.457 & 0.412 & 6.355 & 56.641 \\
\hline Ostracoda & 9.748 & 0.957 & 346.787 & 10.605 & 5.125 & 704.474 & 8.996 & 1.048 & 283.176 \\
\hline Rhynchota ad & 0.065 & 0.036 & 0.071 & 0 & 0 & 0 & 0.037 & 0.719 & 0.667 \\
\hline Rhynchota ne & 0 & 0 & 0 & 0 & 0 & 0 & 0.431 & 0.198 & 3.048 \\
\hline Salamandridae eggs & 4.261 & 1.564 & 82.043 & 0.813 & 2.411 & 31.642 & 2.642 & 3.059 & 90.417 \\
\hline Trichoptera 1 & 0 & 0 & 0 & 0.02 & 1.069 & 0.668 & 0.019 & 0.243 & 0.115 \\
\hline \multicolumn{10}{|l|}{ Terrestial } \\
\hline Acarina & 0.129 & $*$ & 0.183 & 0.059 & 0.001 & 0.037 & 0.056 & 0.001 & 0.075 \\
\hline Araneae & 0.646 & 1.401 & 14.41 & 0.04 & 0.424 & 0.569 & 0.356 & 0.96 & 9.277 \\
\hline Blattodea & 0.129 & 1.415 & 2.175 & 0 & 0 & 0 & 0.131 & 1.781 & 5.897 \\
\hline Coleoptera ad & 1.614 & 2.479 & 49.003 & 0.159 & 1.283 & 5.307 & 1.574 & 5.185 & 107.202 \\
\hline Coleoptera 1 & 0 & 0 & 0 & 0 & 0 & 0 & 0.169 & 0.142 & 0.548 \\
\hline Collembola & 0.323 & 0.004 & 0.46 & 0.02 & 0.001 & 0.013 & 0.037 & $*$ & 0.033 \\
\hline Dermaptera & 0.065 & 0.657 & 0.508 & 0 & 0 & 0 & 0 & 0 & 0 \\
\hline Diplopoda & 0 & 0 & 0 & 0 & 0 & 0 & 0.206 & 1.88 & 6.434 \\
\hline Diptera & 2.389 & 0.634 & 42.567 & 0.04 & 0.053 & 0.114 & 0.506 & 0.164 & 5.901 \\
\hline Formicidae & 1.356 & 0.159 & 12.804 & 0.02 & 0.02 & 0.024 & 0.75 & 0.165 & 9.674 \\
\hline Haplotaxida & 0.065 & 5.051 & 3.602 & 0.02 & 7.649 & 4.705 & 0.075 & 6.963 & 6.201 \\
\hline $\begin{array}{l}\text { Hymenoptera (no } \\
\text { Formicidae) }\end{array}$ & 0.516 & 1.279 & 8.849 & 0.02 & 0.018 & 0.023 & 0.131 & 0.536 & 2.058 \\
\hline Isopoda & 0 & 0 & 0 & 0 & 0 & 0 & 0.056 & 0.128 & 0.243 \\
\hline Isoptera & 0.065 & 0.044 & 0.077 & 0.02 & 0.065 & 0.052 & 0 & 0 & 0 \\
\hline Lepidoptera 1 & 0 & 0 & 0 & 0.02 & 0.361 & 0.233 & 0.169 & 1.388 & 6.172 \\
\hline Orthoptera & 0.323 & 0.473 & 1.681 & 0 & 0 & 0 & 0.037 & 0.065 & 0.09 \\
\hline Pseudoscorpionida & 0.129 & 0.01 & 0.098 & 0 & 0 & 0 & 0 & 0 & 0 \\
\hline Rhynchota ad & 1.356 & 2.98 & 42.748 & 0 & 0 & 0 & 0.806 & 3.134 & 50.33 \\
\hline Rhynchota ny & 0 & 0 & 0 & 0 & 0 & 0 & 0.019 & 0.031 & 0.022 \\
\hline Scorpiones & 0 & 0 & 0 & 0 & 0 & 0 & 0.037 & 0.348 & 0.34 \\
\hline Thysanoptera & 0.129 & 0.002 & 0.184 & 0.02 & 0.001 & 0.013 & 0.037 & $*$ & 0.034 \\
\hline $\mathrm{B}^{\prime}$ & 0.17 & 0.08 & & 0.03 & 0.26 & & 0.06 & 0.26 & \\
\hline Total prey & 1549 & 10245.98 & & 5045 & 6765 & & 5336 & 29729.32 & \\
\hline$\%$ Aquatic prey & 90.77 & 83.41 & & 99.56 & 90.12 & & 94.84 & 77.13 & \\
\hline
\end{tabular}

Larvae and pupae of Diptera were the most important prey category for both sexes in LI (IRI $=1659.300$, FO $=52 \%$ for females; IRI $=3233.842$, $\mathrm{FO}=69 \%$ for males). In $\mathrm{LV}$, both sexes consumed mostly cladocerans (IRI $=6966.545, \mathrm{FO}=73 \%$ for females; $\mathrm{IRI}=7132.059, \mathrm{FO}=69 \%$ for males). TC females focused on cladocerans (IRI $=2078.265, \mathrm{FO}=34 \%$ ) and males on Diptera larvae $(\mathrm{IRI}=2554.867, \mathrm{FO}=69 \%)$. 
Table 2. Hurlbert niche $\left(\mathrm{B}^{\prime}\right)$ width values based on prey number $(\mathrm{N})$ and volume $(\mathrm{V})$ of Lissotriton italicus (LI), Lissotriton vulgaris (LV) and Triturus carnifex (TC) and of females and males from all the study sites.

\begin{tabular}{|c|c|c|c|c|c|}
\hline SPECIES & SITE & SAMPLES & $\begin{array}{c}\text { B'total }^{\prime} \\
\mathrm{N} ; \mathrm{V}\end{array}$ & $\begin{array}{c}\text { B'females }^{\prime} \text { fom } \\
\text { N; }\end{array}$ & $\begin{array}{c}\mathrm{B}^{\prime} \text { males } \\
\mathrm{N} ; \mathrm{V}\end{array}$ \\
\hline \multirow{8}{*}{ LI } & MP & 11 & $0.180 ; 0.330$ & $0.127 ; 0.336$ & $0.168 ; 0.561$ \\
\hline & $\mathrm{E}$ & 8 & $0.443 ; 0.185$ & $0.424 ; 0.154$ & $0.286 ; 0.451$ \\
\hline & NN3 & 30 & $0.192 ; 0.176$ & $0.158 ; 0.300$ & $0.208 ; 0.164$ \\
\hline & P3P & 25 & $0.262 ; 0.303$ & $0.227 ; 0.449$ & $0.200 ; 0.320$ \\
\hline & Po & 17 & $0.170 ; 0.349$ & $0.425 ; 0.364$ & $0.082 ; 0.286$ \\
\hline & PM & 14 & $0.056 ; 0.005$ & $0.068 ; 0.006$ & 0.068 \\
\hline & SV & 22 & $0.220 ; 0.220$ & $0.161 ; 0.219$ & $0.228 ; 0.210$ \\
\hline & W & 15 & $0.462 ; 0.201$ & $0.37 ; 0.203$ & $0.554 ; 0.278$ \\
\hline \multirow{5}{*}{ LV } & $\mathrm{MP}$ & 31 & $0.133 ; 0.312$ & $0.140 ; 0.556$ & $0.126 ; 0.215$ \\
\hline & NN1 & 26 & $0.016 ; 0.224$ & $0.011 ; 0.246$ & $0.020 ; 0.148$ \\
\hline & P5P & 15 & $0.059 ; 0.257$ & $0.069 ; 0.233$ & $0.039 ; 0.666$ \\
\hline & PLV & 22 & $0.262 ; 0.259$ & $0.093 ; 0.350$ & $0.330 ; 0.259$ \\
\hline & $\mathrm{SO}$ & 69 & $0.069 ; 0.364$ & $0.060 ; 0.426$ & $0.076 ; 0.359$ \\
\hline \multirow{12}{*}{$\mathrm{TC}$} & $\mathrm{MP}$ & 20 & $0.158 ; 0.225$ & $0.098 ; 0.195$ & $0.270 ; 0.252$ \\
\hline & C & 14 & $0.398 ; 0.252$ & $0.526 ; 0.314$ & $0.514 ; 0.266$ \\
\hline & $\mathrm{F}$ & 11 & $0.137 ; 0.434$ & $0.143 ; 0.610$ & $0.152 ; 0.429$ \\
\hline & NN1 & 21 & $0.196 ; 0.118$ & $0.216 ; 0.124$ & $0.269 ; 0.202$ \\
\hline & NN3 & 15 & $0.108 ; 0.028$ & $0.220 ; 0.083$ & $0.124 ; 0.029$ \\
\hline & P3P & 20 & $0.139 ; 0.364$ & $0.081 ; 0.428$ & $0.046 ; 0.143$ \\
\hline & P5P & 14 & $0.017 ; 0.075$ & $0.020 ; 0.331$ & $0.036 ; 0.054$ \\
\hline & $\mathrm{Po}$ & 29 & $0.218 ; 0.286$ & $0.194 ; 0.365$ & $0.420 ; 0.330$ \\
\hline & $\mathrm{P}$ & 22 & $0.228 ; 0.341$ & $0.223 ; 0.293$ & $0.242 ; 0.349$ \\
\hline & PLV & 7 & $0.221 ; 0.208$ & $0.255 ; 0.102$ & $0.759 ; 0.578$ \\
\hline & PT & 19 & $0.363 ; 0.425$ & $0.423 ; 0.226$ & $0.187 ; 0.515$ \\
\hline & $\mathrm{SO}$ & 35 & $0.050 ; 0.207$ & $0.065 ; 0.139$ & $0.062 ; 0.429$ \\
\hline
\end{tabular}

Niche width did not differ among the study species (number: $\mathrm{F}_{2,22}=2.158, p=0.139$; volume: $\mathrm{F}_{2,22}=0.456, p=0.640$ ). Both LI and TC showed wider niche width in isolation than in syntopic conditions based on numeric data $\left(\mathrm{F}_{1,16}=4.620, p=0.047\right)$. LI volumetric niche values were wide when the species occurred syntopically with TC and narrow in isolate conditions whereas the opposite was true for TC $(\mathrm{F} 1,16=11.327, p=0.004)$.

Amundsen plots (based on number and volume of prey; Figure 3) showed similar diet patterns for the three study species, all being characterized by a generalist strategy in resource use (most prey categories with $\mathrm{FO}>0.5$ and $\mathrm{Pi}<0.5$ ) and a high diversity among individuals (between phenotype component pattern). Cladocerans confirmed their importance in terms of number in L. vulgaris diet.

Overall, a significant diet overlap was found among study species, populations, and between sexes, especially if prey number is considered (Table 3).

Overall, the observed differences in the trophic spectrum were related to average dissimilarity percentages among all pairs of species (global SIMPER: 70.36\%; pairwise SIMPER: $\mathrm{LI}-\mathrm{TC}=73.1 ; \mathrm{LI}-\mathrm{LV}=68.91 \%$; LV-TC $=68.96 \%$ ). The prey that contributed the most to the observed differences among species were: Cladocera, Diptera larvae and pupae, and Ostracoda (Table S2). However, the observed differences in resources use among newt species were weak on average (ANOSIM: $\mathrm{R}=0.062$ ). Males and females showed a similar trophic spectrum in all the study species (LI: $\mathrm{R}=-0.007 ; \mathrm{LV}: \mathrm{R}=0.021 ; \mathrm{TC}: \mathrm{R}=0.024$ ). 

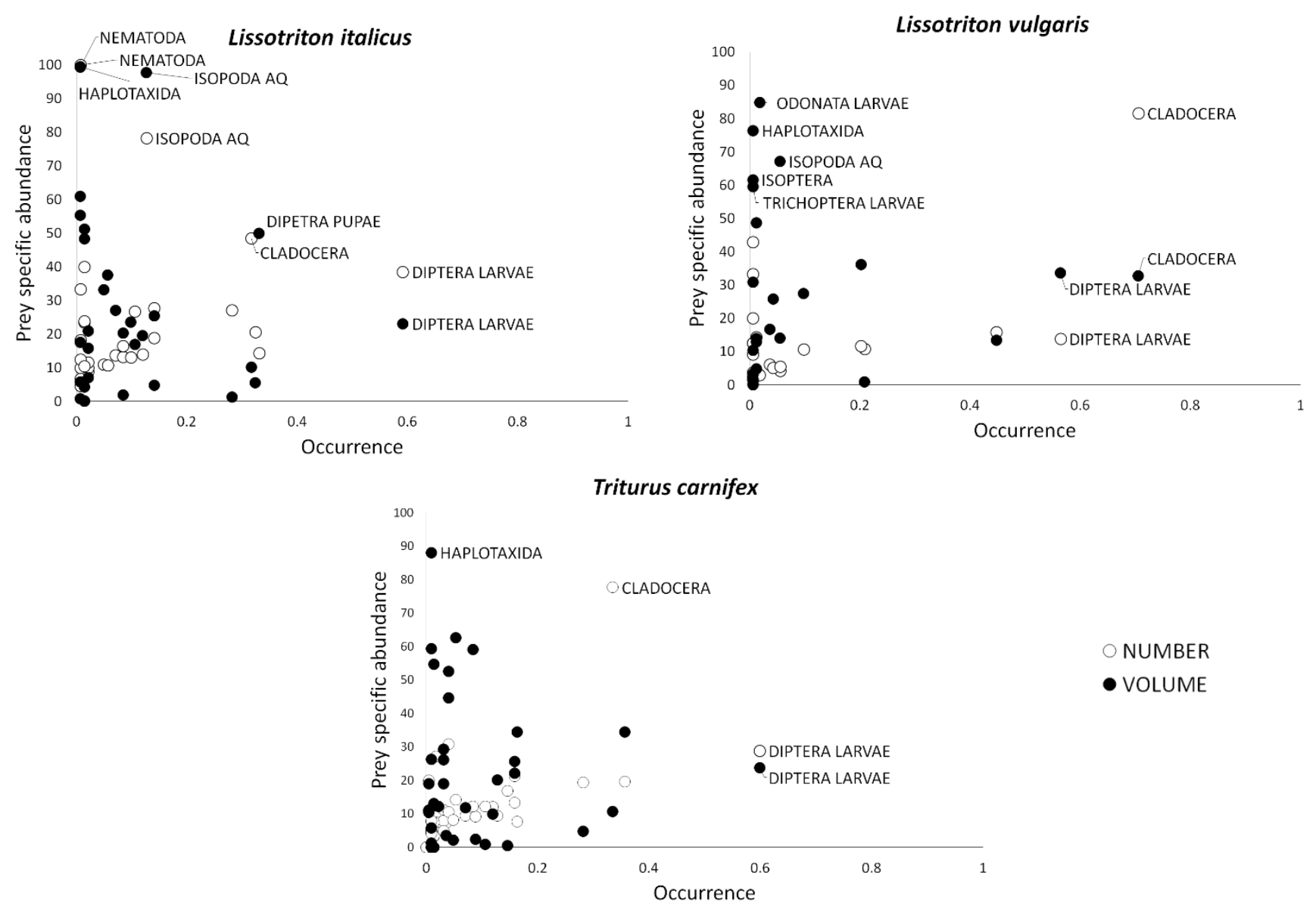

Figure 3. Costello-Amundsen graphical representation of Lissotriton italicus (LI), Lissotriton vulgaris (LV) and Triturus carnifex (TC) based on prey number (empty circles) and volume (black circles). Prey crucial for plot interpretation with dominant, frequent, or with high Pi values are labelled for clarity purposes.

Table 3. Diet overlap values among Lissotriton italicus (LI), Lissotriton vulgaris (LV) and Triturus carnifex (TC) and between females and males within each species from all the study sites. Statistically significant values (i.e., those divergent from the null model) are reported in bold. Obs: observed value; exp: expected value generated by the null model; ns: non statistically significant values.

\begin{tabular}{|c|c|c|c|c|c|}
\hline \multirow[b]{3}{*}{ SPECIES } & \multirow[b]{3}{*}{ SITE } & \multicolumn{4}{|c|}{ SPECIES } \\
\hline & & \multicolumn{2}{|c|}{ NUMBER } & \multicolumn{2}{|c|}{ VOLUME } \\
\hline & & $p($ obs $>\exp )$ & $p($ obs $<\exp )$ & $p($ obs $>\exp )$ & $p($ obs $<\exp )$ \\
\hline LI-LV-TC & Total & $<0.001$ & 1 & 0.150 & 0.850 \\
\hline LI-TC & NN3 & $<0.001$ & 1 & $<0.001$ & 1 \\
\hline LI-TC & P3P & 0.003 & 0.997 & 0.003 & 0.997 \\
\hline LV-TC & NN1 & $<0.001$ & 1 & 1 & $<0.001$ \\
\hline LV-TC & P5P & $<0.001$ & 1 & $<0.001$ & 1 \\
\hline LV-TC & PLV & 0.038 & 0.962 & 1 & $<0.001$ \\
\hline LV-TC & $\mathrm{SO}$ & $<0.001$ & 1 & 0.911 & 0.089 \\
\hline \multirow[t]{2}{*}{ LI-LV-TC } & $\mathrm{MP}$ & $<0.001$ & 1 & 0.265 & 0.735 \\
\hline & & \multicolumn{4}{|c|}{ SEXES } \\
\hline LI & Total & $<0.001$ & 1 & $<0.001$ & 1 \\
\hline LV & Total & $<0.001$ & 1 & 0.002 & 0.998 \\
\hline TC & Total & $<0.001$ & 1 & ns & ns \\
\hline
\end{tabular}


Table 3. Cont.

\begin{tabular}{|c|c|c|c|c|c|}
\hline \multirow{7}{*}{ LI } & MP & 0.007 & 0.993 & ns & ns \\
\hline & $\mathrm{E}$ & 0.075 & 0.925 & ns & ns \\
\hline & NN3 & $<0.001$ & 1 & $<0.001$ & 0.999 \\
\hline & P3P & 0.04 & 0.96 & $<0.001$ & 1 \\
\hline & PM & $<0.001$ & 0.999 & $<0.001$ & 1 \\
\hline & SV & 0.129 & 0.871 & ns & ns \\
\hline & W & 0.041 & 0.959 & $<0.001$ & 1 \\
\hline \multirow{5}{*}{ LV } & $\mathrm{MP}$ & $<0.001$ & 1 & ns & ns \\
\hline & NN1 & $<0.001$ & 1 & ns & ns \\
\hline & P5P & $<0.001$ & 1 & ns & ns \\
\hline & PLV & 0.957 & 0.043 & 0.05 & 0.95 \\
\hline & $\mathrm{SO}$ & $<0.001$ & 1 & ns & ns \\
\hline \multirow{12}{*}{$\mathrm{TC}$} & $\mathrm{MP}$ & $<0.001$ & 1 & ns & ns \\
\hline & C & $<0.001$ & 1 & 0.009 & 0.991 \\
\hline & $\mathrm{F}$ & 0.058 & 0.942 & ns & ns \\
\hline & NN1 & $<0.001$ & 0.999 & $<0.001$ & 1 \\
\hline & NN3 & $<0.001$ & 1 & $<0.001$ & 1 \\
\hline & P3P & 1 & $<0.001$ & 0.98 & 0.02 \\
\hline & P5P & $<0.001$ & 1 & 0.998 & 0.002 \\
\hline & $\mathrm{Po}$ & $<0.001$ & 1 & 0 & 1 \\
\hline & $\mathrm{P}$ & 0.145 & 0.855 & ns & ns \\
\hline & PLV & 0.965 & 0.035 & 1 & $<0.001$ \\
\hline & PT & 0.94 & 0.06 & 0.978 & 0.022 \\
\hline & $\mathrm{SO}$ & $<0.001$ & 1 & 0.04 & 0.96 \\
\hline
\end{tabular}

Newts' diet composition was different among species (PERMANOVA with study sites nested in species; F3,473 = 8.311, $p<0.001$ ) but not between males and females $(\mathrm{F} 3,473=0.895, p=0.552)$. There were significant differences in multivariate dispersion among groups (betadisper, $p<0.01$ ). However, groups with different dispersions also produced low $\mathrm{R}$ values, this suggesting that the observed variation in dispersion values did not bias the results of the tests.

\section{Discussion}

\subsection{Body Size and Diet Composition}

In our assemblages, newts significantly differed in SLV, consistently with the pattern found in other guilds of adult amphibians that are size-structured to reduce predation and competition for food $[5,7,24]$. All the study species differed in body size not only interspecifically but also intersexually with females always larger than males, as appears to be the norm in both Triturus and Lissotriton genera [10].

Overall, all the species showed a narrow trophic niche suggesting that our study wells may represent a suitable habitat for them in terms of food availability and diversity. Indeed, the optimal foraging theory predicts that dietary niche breadth generally decreases as resource availability increases [48].

Newts adopted different feeding strategies depending on species, co-occurrence condition and niche width estimation (numeric vs. volumetric data). Based on numeric data, both T. carnifex and L. italicus (L. vulgaris never occurred in isolation) seemed consistent in narrowing the trophic niche in syntopic condition and widening it in isolation. This result, apparently in contrast with the optimal foraging theory, may suggest that newts reduce prey diversity in presence of heterospecific individuals and increase their food spectrum in terms of prey type in isolation. However, in species-rich assemblages, the narrowing of niche width may be expected as an outcome of resource partitioning [24].

The observed marked differences in newt size and a potential different microhabitat differentiation $[49,50]$ as well as the need to avoid potential interspecific interactions (competition and intraguild predation) may explain why both species specialized on specific prey items in syntopic condition [48]. Conversely, this pattern could be relaxed in absence of heterospecifics by means of ecological release from competing species and constrained by increased intraspecific competition that will tend to reduce availability 
of preferred resources, thus driving individuals to expand their niche to less valuable resources [48].

Based on volumetric data, T. carnifex displayed the same feeding behavior as already observed with numerical data, whereas L. italicus behaved as predicted for an optimal forager by decreasing the niche width in isolation (reduced interspecific competition and intra-guild predation) and increasing it in syntopic conditions. The occurrence of potential interspecific competition can explain the observed differences in L. italicus volumetric niche width values in isolated vs. syntopic conditions [21,23]. Lissotriton italicus, by taking advantage of its small body size, may reduce competition with $T$. carnifex widening the niche width by using resources located in fissures and cracks of well walls not previously included in the diet $[23,51]$. This trophic behaviour may also help the species to avoid predation by T. carnifex which seems to feed on L. italicus in the study area [8]. Conversely, T. carnifex, being competitively dominant to L. italicus because of its larger body size, may act as a generalist consumer restricting its patch utilization to those with higher expectation of yield [52]. This may have led to a consequent reduction in niche width values and to a minimization of the overlap in the resource use with other smaller newts [20,21]. This suggestion is supported by [8] who found that T. carnifex grows larger in size in presence of other smaller newt species in comparison to when it occurs alone.

However, our inferences about the effects of competition on species' niche width should be considered with caution because of the different co-occurrence condition tested and the lack of information about prey dynamics and availability. Prey abundances are known to influence both the selection of food types and microhabitats for foraging [53]. For instance, the magnitude of competition may be sensitive to cladocerans whose density can vary greatly over short time periods and asynchronously between closely adjacent sites often following algal blooms [54].

Newts are considered generalist predators $[6,10,30]$ and the present results confirm only partially this suggestion. All the study species fed on a wide range of aquatic resources, mainly small crustaceans and insect larvae and pupae, together with a small number of terrestrial arthropods collected on the ground during the terrestrial phase or fell into the water [50]. The predominance of aquatic prey was expected since newts are known to consume mostly aquatic prey during the aquatic phase $[6,7,17,18,50]$.

Contrarily to generalists, the observed niche width was often lower than 0.5 [55]. There was, in fact, some selection of the food eaten in favor of aquatic insect larvae and pupae (Diptera) and small crustaceans (mainly cladocerans). Both prey items have been reported to represent a substantial portion of the diet of all the study species throughout their broad distribution range $[5-7,56]$. The data presented here probably reflect the local abundance of both prey categories in our study sites rather than a strong preference for a specific food resource over another [6]. Their diet often changes reflecting fluctuations of prey populations in the environment [57]. This suggests that newts, in accordance with their opportunistic habits [6,58], may have focused on prey that were more energetic, dominant in the aquatic site, and/or easier to catch narrowing their trophic niche width ("optimal foraging theory" [19]). Indeed, insect larvae and pupae are known to be particularly nutritive being rich in lipids [59] whereas cladocerans are ubiquitous and particularly abundant in most freshwater ecosystems [60]. Unfortunately, without information on prey availability in the study sites, we cannot conclude whether the predominance of Cladocera and Diptera larvae and pupae in newt diet depend on their local abundance or on a specific choice.

Size relations are important in aquatic prey-predator systems [61], and correlations between the size of the predator and that of the prey have been reported in several amphibian species $[62,63]$. In the present study, T. carnifex was found to consume not only more massive prey but also more numerous resources than small-bodied newts. Generally, prey diversity should be higher and prey items should be fewer in the stomach of large predators in comparison to small ones [24,64]. However, it is likely that even if large body size enables a wider range of prey sizes to be consumed, all newts consumed small prey 
of similar size in our study sites, in particular small crustaceans [19]. This suggests that T. carnifex did not necessarily avoid small prey that are presumably less profitable than large ones [65]. The species seemed to feed on the same number of food items of smaller L. vulgaris and L. italicus with the inclusion of larger prey $[5,7,24]$. This also supports the idea that even when consuming small prey, T. carnifex larger size provides advantages over smaller newts [65].

\subsection{Comparison in Diet Composition among Species and between Sexes}

All the study species exploited similar resources in terms of number whereas the pattern was less clear when prey volume was considered. No sex-related diet differences were found in numeric and volumetric diet composition in any of the studied species. Moreover, sexes seemed to exploit similar resources in L. italicus and L. vulgaris whereas only weak differences were found in T. carnifex. Sex -based variation in resource use is frequently reported in the literature $[17,18,66]$ and may result from differences in energetic requirements for reproduction [67]. Based on both the low number of gravid females and of empty stomachs detected, newts were probably in an advanced stage of the reproductive season [17]. Males and females had therefore similar energy requirements and were more focused on feeding than on the reproductive process [68].

Prey partitioning is known to be less evident in syntopic assemblages of newts $[69,70]$, especially during the aquatic phase $[7,11]$ because of the unsaturated availability of aquatic resources [71]. This suggests that the high degree of diet overlap observed among species and between sexes may be a consequence of study site oligotrophy [5] and the high availability of small size prey $[56,66]$. Gregarious crustaceans, in particular, being easily collected with limited energy expenditure, were probably consumed in large numbers with a low importance in terms of volume in comparison to larger prey [30,72]. This confirms that differences in body size as well as possible differences in behavior among species and between sexes probably did not affect the type of prey consumed [73].

Prey diet composition and the importance of specific food items seemed to be similar among species and between sexes with subtle differences that were more likely to be a result of among-wells variations in prey availability than interspecific and intersexually differences in prey selection [11]. Ecological conditions, within and outside the study sites, may have played an important role in determining the food composition of newt species [58]. Indeed, most of the study wells were surrounded by pastures and were characterized by small diameter, high depth and a simplified structure lacking a vertical component with specific micro-habitats at different depth (i.e., the shoreline, the water column, the water surface and the bottom) [74]. Such homogenous structure may have prevented deep divergences in micro-habitat use and, consequently, in foraging strategies determining the observed weak dissimilarities among the study species and between sexes $[18,66]$.

Moreover, in absence of fish, newts are the only vertebrate predators. In such a context, as suggested in [30] the necessity for resource partitioning is obviated and a high similarity in diet composition can be tolerated, especially in morphologically similar species, such as L. italicus and L. vulgaris. Moreover, being congeneric species, they are expected to devote considerable time to searching for similar kinds of food items [75-77].

Although we have no information about the availability of invertebrate predators at the study sites, it is likely that they may have altered the outcome of interactions among newt species, especially at high densities. Indeed, the presence or absence of predators is known to affect the selection of prey, as well as microhabitats used for foraging [53].

Finally, it cannot be excluded that the observed variation in diet among species may be a result of the differences in composition within groups rather than among groups. Indeed, individuals are known to differ in types and quantities of ingested prey consuming the whole range of available resources or exploiting specific food items, especially when intra/inter-specific competition is reduced and/or new resources are available ("individual specialization"; [78]). This suggestion is supported by [8] who found that newts showed a 
degree of specialization at our study sites, highly dependent on individual body size and on the complexity of the inhabited assemblage. The occurrence of individual specialization seemed to be more frequent in larger-sized species and in syntopic populations [8].

\section{Conclusions}

The present study showed that artificial aquatic sites are important for our study species that seem to find optimal trophic conditions in terms of environmental characteristics and prey availability and catchability [79]. Several studies have contributed to a greater understanding of newts' diet in natural sites (e.g., $[6,11,16])$ or in artificial water bodies simulating natural ones (e.g., man-made ponds with smooth shorelines and aquatic vegetation) $[7,18]$, whereas those artificial sites extremely different in structure (i.e., wells, drinking troughs, tanks) have been rarely investigated (but see [80]). This suggests that this lack of knowledge has to be solved in order to clarify the role of small artificial aquatic habitats in amphibian ecology and conservation. Once their importance for amphibian survival has been established, the conservation status of such artificial sites should be promoted by legal protection and adopting adequate and effective management strategies respecting amphibian phenology and ecology [2].

Supplementary Materials: The following data are available online at https:/ /www.mdpi.com/1424 -2818/13/1/32/s1, Table S1: Diet composition of males and females in Lissotriton italicus, Lissotriton vulgaris and Triturus carnifex, Table S2: SIMPER analysis of prey ingested by Lissotriton italicus (LI), L. vulgaris (LV) and Triturus carnifex (TC).

Author Contributions: Conceptualization, A.M.B. and L.V.; methodology, A.M.B. and L.V.; software, A.M.B. and L.S.; validation, L.V. and L.L.; formal analysis A.M.B. and L.S.; investigation, J.M. and L.S.; resources, L.S. and L.V.; data curation, J.M. and A.M.B.; writing—original draft preparation, A.M.B. and L.S.; writing—review and editing, M.A.B., J.M., L.L. and L.V.; visualization, L.V.; supervision, A.M.B.; All authors have read and agreed to the published version of the manuscript.

Funding: The Grant to Department of Science, Roma Tre University (MIUR-Italy Dipartimenti di Eccellenza, ARTICOLO 1, COMMI 314-337 LEGGE 232/2016) is gratefully acknowledged.

Institutional Review Board Statement: The study was conducted according to the guidelines of the Declaration of Helsinki, and approved by the Institutional Review Board of MATTM (protocol code 0037132, approved 05-21-2020).

Data Availability Statement: The data presented in this study are reported in the tables and supplementary materials. Data not shown in tables are available on request from the corresponding author. The data are not publicly available due to ongoing longitudinal analysis.

Acknowledgments: The authors are indebted to the Aurunci Natural Park that authorized this research with a special thanks to G. De Marchis and C. Esposito for their help. We also thank G. Simbula for her help in the field.

Conflicts of Interest: The authors declare no conflict of interest.

\section{References}

1. Stuart, S.N.; Chanson, J.S.; Cox, N.A.; Young, B.E.; Rodrigues, A.S.L.; Fischman, D.L.; Waller, R.W. Status and Trends of Amphibian Declines and Extinctions Worldwide. Science 2004, 306, 1783-1786. [CrossRef]

2. Buono, V.; Bissattini, A.M.; Vignoli, L. Can a cow save a newt? The role of cattle drinking troughs in amphibian conservation. Aquat. Conserv. Mar. Freshw. Ecosyst. 2019, 29, 964-975. [CrossRef]

3. Caballero-Diaz, C.; Sanchez-Montes, G.; Butler, H.M.; Vredenburg, V.T.; Martinez-Solano, I. The role of artificial breeding sites in amphibian conservation: A case study in rural areas in central Spain. Herpetol. Conserv. Biol. 2020, 15, 87-104.

4. Vignoli, L.; Macale, D.; Luiselli, L.; Lecis, R.; Casula, P. Are conservation assessments of threatened species reliable? Updated distribution of the Endangered Sardinian newt Euproctus platycephalus and implications for Red List assessments of Italian amphibians. Oryx 2016, 51, 482-488. [CrossRef]

5. Joly, P.; Giacoma, C. Limitation of similarity and feeding habits in three syntopic species of newts (Triturus, Amphibia). Ecography 1992, 15, 401-411. [CrossRef]

6. Fasola, M.; Canova, L. Feeding habits of Triturus vulgaris, T. cristatus and T. alpestris (Amphibia, Urodela) in the northern Apennines (Italy). Ital. J. Zool. 1992, 59, 273-280. 
7. Vignoli, L.; Luiselli, L.; Bologna, M.A. Dietary patterns and overlap in an amphibian assemblage at a pond in Mediterranean Central Italy. Vie Milieu Life Environ. 2009, 59, 47-57.

8. Mirabasso, J.; Bissattini, A.M.; Bologna, M.; Luiselli, L.; Stellati, L.; Vignoli, L. Feeding Strategies of Co-occurring Newt Species across Different Conditions of Syntopy: A Test of the "Within-Population Niche Variation" Hypothesis. Diversity 2020, $12,181$. [CrossRef]

9. Wilbur, H.M. Complex Life Cycles. Annu. Rev. Ecol. Syst. 1980, 11, 67-93. [CrossRef]

10. Wells, K.D. The Ecology and Behavior of Amphibians; University of Chicago Press: Chicago, IL, USA, 2007.

11. Griffiths, R.A.; Mylotte, V.J. Microhabitat selection and feeding relations of smooth and warty newts, Triturus vulgaris and T. cristatus, at an upland pond in mid-Wales. Ecography 1987, 10, 1-7. [CrossRef]

12. Lanza, B.; Andreone, F.; Bologna, M.A.; Corti, C.; Razzetti, E. Amphibia—Fauna d'Italia; Edizioni Calderini: Bologna, Italy, 2007; Volume 42.

13. Sperone, E.; Tripepi, S. Ecological preferences of the Italian newt Triturus italicus (Perracca, 1898) in Calabria. Russ. J. Herpetol. 2005, 12, 216-218.

14. Razzetti, E.; Bernini, F. Triturus Vulgaris. In Atlas of Italian Amphibians and Reptiles Societas Herpetologica Italica; Sindaco, R., Doria, G., Razzetti, E., Bernini, F., Eds.; Edizioni Polistampa: Florence, Italy, 2006.

15. Canestrelli, D.; Salvi, D.; Maura, M.; Bologna, M.A.; Nascetti, G. One species, three Pleistocene evolutionary histories: Phylogeography of the crested newt, Triturus carnifex. PLoS ONE 2012, 7, e41754. [CrossRef]

16. Cicort-Lucaciu, A.S.; Ardeleanu, A.; Cupsa, D.; Naghi, N.; Dalea, A. The trophic spectrum of a Triturus cristatus (Laurentus 1768) population from Plopis Mountains area (Bihor County, Romania). North West. J. Zool. 2005, 1, 31-39.

17. Covaciu-Marcov, S.D.; Cicort-Lucaciu, A.Ş.; Mitrea, I.; Sas, I.; Căuş, A.V.; Cupşa, D. Feeding of three syntopic newt species (Triturus cristatus, Mesotriton alpestris and Lissotriton vulgaris) from Western Romania. North West. J. Zool. 2010, 6, 95-108.

18. Covaciu-Marcov, S.; Cicort-Lucaciu, A.; Sas, I.; Cupşa, D.; Kovacs, E.; Ferenţi, S. Food composition of some low altitude Lissotriton montandoni (Amphibia, Caudata) populations from North-Western Romania. Arch. Biol. Sci. 2010, 62, 479-488. [CrossRef]

19. Roşca, I.; Gherghel, I.; Strugariu, A.; Zamfirescu, Ş.R. Feeding ecology of two newt species (Triturus cristatus and Lissotriton vulgaris) during the reproduction season. Knowl. Manag. Aquat. Ecosyst. 2013, 408, 5. [CrossRef]

20. Pianka, E.R. Competition and Niche Theory. Theoretical Ecology Principles and Applications; Blackwell: Oxford, UK, 1981; pp. 167-196.

21. Bissattini, A.M.; Vignoli, L. Let's eat out, there's crayfish for dinner: American bullfrog niche shifts inside and outside native ranges and the effect of introduced crayfish. Biol. Invasions 2017, 19, 2633-2646. [CrossRef]

22. Winemiller, K.O.; Pianka, E.R.; Vitt, L.J.; Joern, A. Food web laws or niche theory? Six independent empirical tests. Am. Nat. 2001, 158, 193-199. [CrossRef]

23. Lejeune, B.; Bissey, L.; Didaskalou, E.A.; Sturaro, N.; Lepoint, G.; Denoël, M. Progenesis as an intrinsic factor of ecological opportunity in a polyphenic amphibian. Funct. Ecol. 2020. [CrossRef]

24. Vignoli, L.; Bissattini, A.M.; Luiselli, L. Food partitioning and the evolution of non-randomly structured communities in tailed amphibians: A worldwide systematic review. Biol. J. Linn. Soc. 2016, 120, 489-502. [CrossRef]

25. Cerini, F.; Bologna, M.A.; Vignoli, L. Dragonflies community assembly in artificial habitats: Glimpses from field and manipulative experiments. PLoS ONE 2019, 14, e0214127. [CrossRef]

26. Garcia-Gonzalez, C.; Garcia-Vazquez, E. The value of traditional troughs as freshwater shelters for amphibian diversity. Aquat. Conserv. Mar. Freshw. Ecosyst. 2010, 21, 74-81. [CrossRef]

27. Novellino, D. An Account of Basket Weaving and the Use of Fibre Plants in the Mount Aurunci Regional Park (Central Italy). In Proceedings of the Fourth International Conference of Ethnobotany (ICEB 2005), Istanbul, Turkey, 21-26 August 2005; pp. 317-326.

28. Romano, A.; Montinaro, G.; Mattoccia, M.; Sbordoni, V. Amphibians of the Aurunci Mountains (Latium, Central Italy). Checklist and conservation guidelines. Acta Herpetol. 2007, 2, 17-25.

29. Solé, M.; Beckmann, O.; Pelz, B.; Kwet, A.; Engels, W. Stomach-flushing for diet analysis in anurans: An improved protocol evaluated in a case study in Araucaria forests, southern Brazil. Stud. Neotrop. Fauna Environ. 2005, 40, 23-28. [CrossRef]

30. Griffiths, R.A. Feeding Niche Overlap and Food Selection in Smooth and Palmate Newts, Triturus vulgaris and T. helveticus, at a Pond in Mid-Wales. J. Anim. Ecol. 1986, 55, 201. [CrossRef]

31. Bellocq, M.I.; Kloosterman, K.; Smith, S.M. The diet of coexisting species of amphibians in Canadian jack pine forests. Herpetol. J. 2000, 10, 63-68.

32. Pinkas, L.; Oliphant, M.S.; Iverson, L.K. Food habits of albacore, blue fin tuna, and bonito in California waters. Fish Bull. 1971, 152, 1-105.

33. Levins, R. Evolution in Changing Environments; Princeton University Press: Princeton, NJ, USA, 1968.

34. Hurlbert, S.H. The measurement of nice overlap and some relatives. Ecology 1978, 59, 67-77. [CrossRef]

35. Grossman, G.D. Food resource partitioning in a rocky intertidal fish assemblage. J. Zool. 1986, 1, 317-355. [CrossRef]

36. Costello, M.J. Predator feeding strategy and prey importance: A new graphical analysis. J. Fish Biol. 1990, 36, 261-263. [CrossRef]

37. Amundsen, P.-A.; Gabler, H.-M.; Staldvik, F.J. A new approach to graphical analysis of feeding strategy from stomach contents data-modification of the Costello (1990) method. J. Fish Biol. 1996, 48, 607-614. [CrossRef]

38. Gotelli, N.J.; Entsminger, G.L. EcoSim: Null Modeling Software for Ecology. Version 7.0. 2011. Available online: http:// garyentsminger.com/ecosim/index.htm (accessed on 5 May 2020). 
39. Vignoli, L.; Luiselli, L. Dietary relationships among coexisting anuran amphibians: A worldwide quantitative review. Oecologia 2011, 169, 499-509. [CrossRef]

40. Anderson, M.J. A new method for non-parametric multivariate analysis of variance. Austral. Ecol. 2001, $26,32-46$.

41. Oksanen, J.; Blanchet, F.G.; Friendly, M.; Kindt, R.; Legendre, P.; McGlinn, D.; Minchin, P.R.; O’Hara, R.B.; Simpson, G.L.; Solymos, P.; et al. Vegan: Community Ecology Package. R Package Version 2.5-6. 2019. Available online: https://CRAN.R-project.org/ package $=$ vegan $($ accessed on 5 May 2020).

42. Anderson, M.J.; Walsh, D.C.I. PERMANOVA, ANOSIM, and the Mantel test in the face of heterogeneous dispersions: What null hypothesis are you testing? Ecol. Monogr. 2013, 83, 557-574. [CrossRef]

43. Warton, D.I.; Wright, S.T.; Wang, Y. Distance-based multivariate analyses confound location and dispersion effects. Methods Ecol. Evol. 2012, 3, 89-101. [CrossRef]

44. Clarke, K.R.; Warwick, R.M. Change in Marine Communities: An Approach to Statistical Analysis and Interpretation, 2nd ed.; PRIMER-E: Plymouth, UK, 2001; p. 172.

45. Creque, S.M.; Czesny, S.J. Diet overlap of non-native alewife with native yellow perch and spottail shiner in nearshore waters of southwestern Lake Michigan, 2000-2007. Ecol. Freshw. Fish 2011, 21, 207-221. [CrossRef]

46. Clarke, K.R.; Tweedley, J.R.; Valesini, F.J. Simple shade plots aid better long-term choices of data pre-treatment in multivariate assemblage studies. J. Mar. Biol. Assoc. U. K. 2014, 94, 1-16. [CrossRef]

47. Hammer, Ø.; Harper, D.A.T.; Ryan, P.D. PAST: Paleontological statistics software package for education and data analysis. Palaeontol. Electron. 2001, 4, 1-9.

48. Schoener, T.W. Theory of Feeding Strategies. Annu. Rev. Ecol. Syst. 1971, 2, 369-404. [CrossRef]

49. Vignoli, L.; Bologna, M.A.; Luiselli, L. Seasonal patterns of activity and community structure in an amphibian assemblage at a pond network with variable hydrology. Acta Oecol. 2007, 31, 185-192. [CrossRef]

50. Vignoli, L.; Bombi, P.M.; D'Amen, M.; Bologna, M.A. Seasonal variation in the trophic niche of a heterochronic population of Triturus alpestris apuanus from the south-western Alps. Herpetol. J. 2007, 17, 183-191.

51. Rudolph, D.C. Aspects of the Larval Ecology of Five Plethodontid Salamanders of the Western Ozarks. Am. Midl. Nat. 1978, 100, 141. [CrossRef]

52. Pianka, E.R. Evolutionary Ecology, 5th ed.; Pianka, E.R., Ed.; HarperCollins College Division: New York, NY, USA, 2011; pp. 279-289.

53. Walton, B.M. Salamanders in forest-floor food webs: Environmental heterogeneity affects the strength of top-down effects. Pedobiologia 2005, 49, 381-393. [CrossRef]

54. Sun, X.; Tao, M.; Qin, B.; Qi, M.; Niu, Y.; Zhang, J.; Ma, Z.; Xie, P. Large-scale field evidence on the enhancement of small-sized cladocerans by Microcystis blooms in Lake Taihu, China. J. Plankton Res. 2012, 34, 853-863. [CrossRef]

55. MacArthur, R.; Levins, R. The Limiting Similarity, Convergence, and Divergence of Coexisting Species. Am. Nat. 1967, 101, 377-385. [CrossRef]

56. Sucea, F.; Cicort-Lucaciu, A.S.; Covaci, R.F.; Dimancea, N. Note on the diet of two newt species in Jiului Gorge National Park, Romania. Herpetol. Rom. 2014, 8, 11-27.

57. Hamilton, W.J., Jr. The Food and Feeding Habits of Some Eastern Salamanders. Copeia 1932, 1932, 83. [CrossRef]

58. Kutrup, B.; Akir, E.; Yilmaz, N. Food of the banded newt, Triturus vittatus ophryticus (Berthold, 1846), at different sites in Trabzon. Turk. J. Zool. 2005, 29, 83-89.

59. Brooks, J.S.; Calver, C.M.; Dickman, R.C.; Meathrel, E.C.; Bradley, S.J. Does intraspecific variation in the energy value of a prey species to its predators matter in studies of ecological energetics? A case study using insectivorous vertebrates. Ecoscience 1996, 3 , 247-251. [CrossRef]

60. Forró, L.; Korovchinsky, N.M.; Kotov, A.A.; Petrusek, A. Global diversity of cladocerans (Cladocera; Crustacea) in freshwater. In Freshwater Animal Diversity Assessment; Springer: Dordrecht, The Netherlands, 2007; pp. 177-184.

61. Osenberg, C.W.; Mittelbach, G.G. Effects of Body Size on the Predator-Prey Interaction Between Pumpkinseed Sunfish and Gastropods. Ecol. Monogr. 1989, 59, 405-432. [CrossRef]

62. Braña, F.; de la Hoz, M.; Lastra, C. Alimentaciòn y relaciones tròficas entre las larvas de Triturus marmoratus, T. alpestris y T. helveticus (Amphibia: Caudata). Doñana Acta Venebrata 1986, 13, 21-33.

63. Toft, C.A. Feeding ecology of thirteen syntopic species of anurans in a seasonal tropical environment. Oecologia 1980, 45, 131-141. [CrossRef] [PubMed]

64. Schoener, T.W. Resource Partitioning in Ecological Communities. Science 1974, 185, 27-39. [CrossRef] [PubMed]

65. Denoël, M.; Whiteman, H.H.; Wissinger, S.A. Temporal shift of diet in alternative cannibalistic morphs of the tiger salamander. Biol. J. Linn. Soc. 2006, 89, 373-382. [CrossRef]

66. David, A.; Ferenti, S.; Hodişan, O.; Bogdan, H.V.; Gale, O. The food analysis of a Triturus cristatus population near Ignesti locality, Arad County, Romania. Herpetol. Rom. 2009, 3, 47-52.

67. Bull, E.L. Diet and prey availability of Columbia spotted frogs in northeastern Oregon. Northwest Sci. 2003, 77, 349-356.

68. Dobre, F.; Bucur, D.M.; Mihuț, R.; Birceanu, M.; Gale, O. Data on the food composition of a Triturus cristatus (Laur. 1768) population from ,Jiului Gorge" National Park, Romania. Biharean Biol. 2007, 1, 23-28.

69. Avery, R.A. Food and Feeding Relations of Three Species of Triturus (Amphibia Urodela) during the Aquatic Phases. Oikos 1968, 19, 408. [CrossRef] 
70. Stoch, E.; Dolce, S. Alimentazione e rapporti alimentari di Triturus alpestris (Laur.), T. cristatus carnifex (Laur.) e Triturus vulgaris meridionalis (Boul.). (Osservazioni sull'alimentazione degli Anfibi: III). Quaderni ETP. Udine 1984, 9, 17-28.

71. Griffiths, R.A. Microhabitat and Seasonal Niche Dynamics of Smooth and Palmate Newts, Triturus vulgaris and T. helveticus, at a Pond in Mid-Wales. J. Anim. Ecol. 1987, 56, 441. [CrossRef]

72. Hyslop, E.J. Stomach contents analysis-a review of methods and their application. J. Fish Biol. 1980, 17, 411-429. [CrossRef]

73. Araújo, M.S.; dos Reis, S.F.; Giaretta, A.A.; Machado, G.; Bolnick, D.I. Intrapopulation diet variation in four frogs (Leptodactylidae) of the Brazilian Savannah. Copeia 2007, 4, 855-865. [CrossRef]

74. Denoël, M.; Joly, P. Adaptive significance of facultative paedomorphosis in Triturus alpestris (Amphibia, Caudata): Resource partitioning in an alpine lake. Freshw. Biol. 2001, 46, 1387-1396. [CrossRef]

75. Giller, P.S. Community Structure and the Niche; Chapman and Hall: London, UK, 1986.

76. Hutchinson, G.E. Homage to Santa Rosalia or Why Are There So Many Kinds of Animals? Am. Nat. 2002, 93, 145-159. [CrossRef]

77. Hutchinson, G.E.; MacArthur, R.H. A Theoretical Ecological Model of Size Distributions among Species of Animals. Am. Nat. 2002, 93, 117-125. [CrossRef]

78. Bolnick, D.I.; Svanbäck, R.; Fordyce, J.A.; Yang, L.H.; Davis, J.M.; Hulsey, C.D.; Forister, M.L. The ecology of individuals: In-cidence and implications of individual specialization. Am. Nat. 2003, 161, 1-28. [CrossRef]

79. Sas, I.; Covaciu-Marcov, S.D.; Strugariu, A.; David, A.; Ilea, C. Food habit of Rana (Pelophylax) kl. esculenta females in a new recorded E-system population from a forested habitat in North-Western Romania. Turk. J. Zool. 2009, 33, 1-5.

80. Salvidio, S.; Costa, A.; Crovetto, F. Individual Trophic Specialisation in the Alpine Newt Increases with Increasing Resource Diversity. Ann. Zool. Fenn. 2019, 56, 17-24. [CrossRef] 